\title{
KOŚCIOLY RZYMSKOKATOLICKIE NA UKRAINIE LEWOBRZEŻNEJ (XIX-XX WIEK). PRZEGLĄD RETROSPEKTYWNY
}

\section{Streszczenie}

W artykule dokonano krótkiej retrospektywy historii kościołów rzymskokatolickich na Ukrainie Lewobrzeżnej w XIX-XX wieku, od budowy w czasach Imperium Rosyjskiego do losów w czasach radzieckich, i wspomniano o współczesnej sytuacji z kościołami już w niepodległej Ukrainie. Na początku zostały przeanalizowane czynniki, które spowodowały powstanie licznej Polonii na obszarach Ukrainy Lewobrzeżnej, czyli w guberniach: jekaterynosławskiej, połtawskiej, charkowskiej oraz czernihowskiej. Na tych terenach dzięki staraniom miejscowych Polaków zbudowano 12 kościołów w: Czernihowie, Nieżynie, Połtawie, Romnie, Krzemieńczuku, Jekaterynosławiu, Kamieńskim, Jenakijewie, Mariupolu, Bachmucie, Charkowie i Sumach.

W podsumowaniu artykułu zaznaczono, że każdy kościół od momentu swojej konsekracji stał się centrum życia nie tylko społeczności polskiej, ale także miejscem spotkań katolików różnych narodowości. Podczas okupacji Ukrainy przez wojska bolszewickie kościoły zostały zamknięte, a część z nich zburzono. Tylko nieliczne świątynie przetrwały do naszych czasów. Dziś stanowią one ważne pamiątki architektury sakralnej, zdobiące centrum ukraińskich miast.

Słowa kluczowe: kościół; Ukraina Lewobrzeżna; architektura sakralna; polska mniejszość; Polonia

Historia polskich świątyń na Ukrainie Lewobrzeżnej jest bardzo ciekawym zagadnieniem i do dziś pozostaje ważnym obszarem badań polskich i ukraińskich naukowców. Losy architektury sakralnej są analogiczne do tragicznych losów Polaków na tym obszarze, których przodkowie zbudowali i wyposażyli kościo-

* Lubow Żwanko - prof. zw., dr hab., Kharkiv State Veterinary Academy;

e-mail: zhvan2012@gmail.com

https://orcid.org/0000-0002-1107-449X 
ły. W czasach stalinowskiego terroru bardzo dużo świątyń zostało zamkniętych, przebudowanych lub zburzonych. Również liczni Polacy, a wśród nich księża, jako wrogowie narodu, zostali zamordowani. Jak zauważyła historyk Natalia Rublowa, pierwsze 20-lecie rządu bolszewików zakończyło się dla wspólnoty rzymskokatolickiej katastrofalnymi skutkami. Na całej Ukrainie sowieckiej zostały wstrzymane wszystkie publiczne formy życia religijnego, świątynie zamknięte i splądrowane, księża wydaleni, uwięzieni, straceni, a wierzący poddani represjom $^{1}$. Prezentowany artykuł jest krótkim szkicem historycznym, przedstawiającym okoliczności powstania kościołów rzymskokatolickich, opisem ich architektury oraz losów świątyń po ustanowieniu władzy sowieckiej na Ukrainie. Praca została oparta na dwóch fundamentalnych publikacjach naukowych. W książce Zygmunta Lukawskiego, profesora Uniwersytetu Jagiellońskiego, Ludność polska w Rosji 1863-1914, można odnaleźć informacje dotyczące procesu wznoszenia kościołów przez Polaków na Ukrainie ${ }^{2}$. Autor wskazuje na kościół jako miejsce integrujące miejscową Polonię:

Był tutaj wysoki urzędnik i oficer, generał i żołnierz, dama z wysokiego świata i robotnik, policjant i więzień. Po skończeniu mszy ta jedność się skończyła i każdy szukał swojego towarzystwa, zgodnie ze swoim statusem³.

Ważnym źródłem naukowym jest również publikacja Marka Mądzika, Mariusza Korzeniowskiego, Krzysztofa Latawca i Dariusza Tarasiuka Polacy na wschodniej Ukrainie w latach 1832-1921. Książka jest wynikiem kilkuletnich badań i stanowi jak do tej pory jedynie tak obszerną monografię dotyczącą Polaków na Ukrainie ${ }^{4}$. Niezwykle cenna jest publikacja ukraińskiej badaczki Olgi Bakowieckiej, poświęcona historii Kościoła rzymskokatolickiego na Ukrainie w końcu XVIII-XIX wieku. W rozprawie ukazano m.in. proces formowania parafii katolickich $^{5}$.

W wielu pracach napisanych przez autorkę tego artykułu i opublikowanych w Polsce na temat historii Polaków na Ukrainie Lewobrzeżnej ${ }^{6}$, Polonii Char-

${ }^{1}$ N. Rublowa, Rimo-katolicka cerkwa w ukrainskij prowicjii 1920-1930 ch. Rr.,Fastiszczina, s. 332; Н. Рубльова, Римо-католицька иерква в українській провінції 1920-1930-х рр.: Фастівщина, с. 332.

${ }^{2}$ Z. Łukawski, Ludność polska w Rosji 1863-1914, Wrocław-Warszawa-Kraków 1978.

${ }^{3}$ Tamże, s. 52.

${ }^{4}$ M. Mądzik, M. Korzeniowski, K. Latawiec, D. Tarasiuk, Polacy na wschodniej Ukrainie w latach 1832-1921, Lublin 2012, wyd. 2 - 2014, ss. 294. Recenzję pierwszego wydania książki opublikowano na ukraińskim portalu HISTORIANS.IN.UA: L. Żwanko, Mądzik M., Korzeniowski M., Latawiec K., Tarasiuk D., Polacy na wschodniej Ukrainie w latach 1832-1921. Lublin: UMCS Wydawnictwo Uniwersytetu Marii Curie-Skłodowskiej, 2012. 230 s., http://www.historians.in.ua/index. php/en/novi-knizhki/859-marek-mdzik-mariusz-korzeniowski-kryzsztof-latawiec-dariusz-tarasiuk-polacy-na-wschodniej-ukrainie-w-latach-1832-1921-lublin-2012-230-s (dostęp: 27.10.2016).

${ }^{5}$ O. Bakowećka, Rimo-katotycka cerkwa w Ukrajini w kinci XVIII-XIX stolitti, s. 218; О. Баковецька , Римо-католицька церква в Украӥні в кінці XVIII - XIX столітті, с. 218.

${ }^{6}$ L. Żwanko, Polacy na Ukrainie Lewobrzeżnej: geneza, symbole tożsamości (XIX-początek $X X$ w.), „Europa Orientalis. Studia z dziejów Europy Wschodniej i Państw Bałtyckich”, 8 (2017) s. 21-46. 
kowa ${ }^{7}$, działalności architektów polskiego pochodzenia ${ }^{8}$, a mianowicie twórcy Kościoła Bolesława Michałowskiego ${ }^{9}$, znajdują się materiały dotyczące również historii polskiej architektury sakralnej. Należy podkreślić, że autorka prowadząc badania, napotykała na różnego rodzaju problemy. W niektórych przypadkach nie udało się określić daty budowy kościoła, brakuje informacji o architekcie, a nawet o samej wspólnocie polskiej, która inicjowała tę budowę. W związku z tym posiłkowano się publikacjami miejscowych historyków-krajoznawców umieszczonych na stronach internetowych.

W XIX wieku na terenach Ukrainy Lewobrzeżnej znajdowały się cztery gubernie: jekaterynosławska (miasto gubernialne - Jekaterynosław, współcześnie Dniepr), połtawska (miasto gubernialne Połtawa), charkowska (gubernialne miasto Charków) oraz czernihowska (gubernialne miasto Czernihów). Od XIX do początku XX wieku dzięki staraniom miejscowych Polaków zbudowano 12 kościołów w miejscowościach: Czernihów (1838/1858), Nieżyn (koniec XIX wieku), Połtawa (1859), Romny (początek XX wieku), Krzemieńczuk (1910), Jekaterynosław (1877), Kamieńskie (1897), Jenakijewo (1900), Mariupol (1860), Bachmut (1903), Charków (1891) i Sumy (1911). Na uwagę zasługuje fakt, że kościoły zbudowano mimo braku na tym obszarze zwartego osadnictwa polskiego, a powstałe ośrodki stanowiły emanację procesów migracyjnych. W przeciwieństwie do Polaków Kraju Południowo-Zachodniego kształtujące się tu skupiska osadników polskich nie otrzymywały dużego wsparcia materialnego ${ }^{10}$.

W tym aspekcie ważne jest krótkie wyjaśnienie przyczyn osiedlenia się Polaków na terenach tych czterech guberni ukraińskich oraz tworzenia przez nich miejscowej wspólnoty polskiej poza granicami ojczystego kraju, tzw. Polonii ${ }^{11}$.

Należy wyraźnie podkreślić, iż obecność Polaków w ówczesnych guberniach zadnieprzańskich wynikała $\mathrm{z}$ innych przesłanek niż miało miejsce na terenie Ukrainy Zachodniej czy Prawobrzeżnej. Pojawienie się Polaków na tych terenach miało istotny wpływ na tutejsze społeczeństwo. Wielkość, liczebność, skład społeczny i dynamika rozwoju ośrodków polskich na przedstawionym obszarze w dużej mierze zależały po pierwsze od atrakcyjności regionu. Niewątpliwie to, co przyciągało Polaków, niezależnie od kondycji społeczniej, to dynamiczny rozwój gospodarczy wschodnich guberni ukraińskich w drugiej połowie XIX wieku. To doprowadziło do napływu w poszukiwaniu pracy mieszkańców Królestwa Polskiego ${ }^{12}$.

Następnym czynnikiem powodującym zwiększanie liczebności miejscowej Polonii byli absolwenci cesarskich uczelni, którzy otrzymywali posadę m.in. w mia-

${ }^{7}$ L. Żwanko, Polonia Charkowa w XVIII-XIX wieku, „Wiadomości Historyczne”, (2016) nr 6, s. 26-29.

${ }^{8}$ L. Żwanko, Spuścizna architektów Polaków na mapie Charkowa, w: Polskije i rossijskie architektory w XIX i XX wiekach. Polish and-russian architects in 19-th And 20-th Centuries, t. 4, red. J. Malinowski, I. Gawrasz, Warszawa-Toruń 2018, s. 181-196.

${ }^{9}$ L. Żwanko, Polscy architekci Charkowa - Bolesław Michałowski i Marian Józef Zdzisław Charmański: szkic o życiu i twórczości, „Studia z Architektury Nowoczesnej”, 6 (2018) s. 47-69.

${ }^{10}$ Mądzik, Korzeniowski, Latawiec, Tarasiuk, Polacy na wschodniej Ukrainie, s. 10.

${ }^{11}$ Żwanko, Polacy na Ukrainie Lewobrzeżnej, s. 22.

${ }^{12}$ Mądzik, Korzeniowski, Latawiec, Tarasiuk, Polacy na wschodniej Ukrainie, s. 10. 
stach Ukrainy Lewobrzeżnej. W tym kontekście warto zwrócić uwagę na absolwentów rosyjskich uczelni architektonicznych (Cesarska Akademia Sztuk Pięknych i Instytut Inżynierów Cywilnych w Petersburgu $)^{13}$. Wśród nich był m.in. założyciel dynastii architektów Edward Julian Charmański, który po ukończeniu Szkoły Budownictwa w Petersburgu osiedlił się wraz z żoną w Jekaterynosławiu (1859) ${ }^{14}$, gdzie otrzymał posadę pomocnika architekta $\mathrm{w}$ gubernialnej komisji drogowo-budowlanej ${ }^{15}$. Również jego synowie byli architektami. Stanisław Antoni pracował od lat 90. XIX wieku do 1914 roku na stanowisku jekaterynosławskiego inżyniera gubernialnego. Natomiast Zbysław Marian w 1890 roku przeniósł się do Charkowa, gdzie w latach 1896-1917 pracował na stanowisku ziemskiego inżyniera gubernialnego oraz kierował wydziałem technicznym Urzędu Miejskiego ${ }^{16}$. W Jekaterynosławiu mieszkała i pracowała również inna polska rodzina architektów: Albert i jego syn Leonid Brodnicki ${ }^{17}$.

Ważniejszym czynnikiem, który wpływał na podjęcie decyzji przez Polaków o zamieszkaniu na stałe w miastach Ukrainy Lewobrzeżnej, był dostęp do uczelni wyższych i ośrodków kultury.

W Charkowie funkcjonowały wówczas uczelnie wyższe: cesarski uniwersytet (1805) i dwie uczelnie techniczne. Miasto miało też status kulturalnej stolicy regionu. Wśród Polaków, którzy pozostali na Lewobrzeżu, byli również zdemobilizowani polscy żołnierze, którzy osiadali się w miejscach dotychczasowej służby, podejmując zatrudnienie w rzemiośle lub zasilając rzesze robotników najemnych ${ }^{18}$.

Następną grupę Polaków zamieszkujących wspomniane gubernie stanowili przymusowo osiedleni $w$ nich przez władze carskie w wyniku represji za działalność patriotyczną. Często po odbyciu kary zesłania w syberyjskich guberniach władze zabraniały Polakom powrotu do Ojczyzny i nakazywały przymusowe osiedlenie w wyznaczonym rejonie Imperium Rosyjskiego. W ten sposób poprzez przymusowe oraz dobrowolne osadnictwo dokonywał się napływ ludności polskiej na teren Ukrainy Lewobrzeżnej. Proces ten stopniowo narastał przez XIX stulecie oraz pierwsze dziesięciolecia XX wieku. Doprowadził on do ukształtowania się większych zbiorowości polskich w miastach, miasteczkach a nawet na wsiach Ukrainy Lewobrzeżnej.

${ }^{13}$ M. Omilanowska, H. Bilewicz, Architektura, polityka, tożsamość. Z badań nad karierami polskich wychowanków rosyjskich uczelni architektonicznych w XIX i na początku XX wieku (casus Józefa Padlewskiego), w: Polska-Rosja. Sztuka i historia. Sztuka polska, sztuka rosyjska i polsko-rosyjskie kontakty artystyczne do poczatku XX wieku, red. J. Malinowski, I. Gavrash, N. Mizerniuk-Rotkiewicz, Warszawa-Torun 2013, s. 300.

${ }^{14}$ Księga pamiątkowa inżynierów cywilnych Polaków wychowanków Instytutu Inżynierów Cywilnych w Petersburgu, Warszawa 1937, s. 57.

${ }^{15}$ В. Старостін, Польська родина катеринославських архітекторів, http://archive.li/7BBuj \#selection-1217.0-1417.30 (dostęp: 12.05.2017).

${ }^{16}$ Ю. Полякова, Архитеторы Харькова польского происхождения, w: Polska diaspora w Charkowie. Historia i współczesność. Харків 2014, s. 136.

17 М. Чабан, Родина архітекторів Бродницьких на Катеринославщині, http://www. sicheslav.porogy.org/2007/13/historyland/ (dostęp: 15.05.2017).

${ }^{18}$ Mądzik, Korzeniowski, Latawiec, Tarasiuk, Polacy na wschodniej Ukrainie, s. 16. 
Mechanizm tworzenia Polonii jako całościowej jednostki mniejszości w różnych miastach Ukrainy Lewobrzeżnej na przykładzie Charkowa podał Artur Kijas. Ukazał on proces tworzenia Polonii poprzez zwiększenie napływu coraz większej liczby Polaków do miasta oraz ich samoorganizację i pielęgnowanie tożsamości narodowej i religijnej jako części polskiej wspólnoty:

1. czas niezorganizowanego, a nawet niekiedy przypadkowego napływu do miasta Polaków,

2. czas pewnego rozproszenia żywiołu polskiego w Charkowie,

3. obejmuje zorganizowane działania kolonii charkowskiej dla wspólnego dobra mieszkających w mieście Polaków ${ }^{19}$.

Powolny procesy kształtowania się Polonii na tym obszarze rozpoczął się w pierwszych trzech dekadach XIX stulecia. Najpierw były to kilkudziesięcioosobowe skupiska zamieszkujące przede wszystkim miasta gubernialne: Charków, Jekaterynosław, Czernihów i Połtawę. Na początku lat 60. XIX wieku pojawiły się pierwsze dane statystyczne, które umożliwiają poznanie liczebności Polaków zamieszkujących Lewobrzeżną Ukrainę. Jednak warto zwrócić uwagę, że były one nieprecyzyjne, ponieważ komitety statystyczne działające $\mathrm{w}$ omawianych guberniach stroniły od przeprowadzania dokładniej identyfikacji według kryterium narodowościowego. Natomiast urzędnicy rosyjscy utożsamiali osoby należące do Kościoła katolickiego obrządku łacińskiego z przedstawicielami narodu polskiego ${ }^{20}$.

Zasadniczym dowodem wzrostu liczebności ludności polskiej, a jednocześnie ukształtowanie się jej jako samowystarczalnej jednostki było budownictwo kościołów. Świątynia była symbolem tego, że społeczność polska jest już mocna gospodarczo, ponieważ może na własny koszt wznieść i wyposażyć kościół. Dodatkowo budowniczowie korzystali z usług polskiego architekta, który wywodził się z ich środowiska. Fakt ten potwierdza tezę Zygmunta Łukawskiego, że polskie diaspory szukały dla takich zadań architektów w swoich środowiskach.

Nie trzeba chyba wyjaśniać, że w trakcie budowy katolicy starali się maksymalnie wykorzystać własne siły fachowe. Najczęściej projekt kościoła opracował i nadzorował budowę miejscowy architekt - Polak. Władze udzielały zezwoleń na budowę kościołów i pomieszczeń. $Z$ czasem, w miarę rozbudowy miast, kościoły te znalazły się w samym centrum ${ }^{21}$.

Należy zwrócić uwagę, że problemem nie było tylko wybudowanie kościoła, ale przede wszystkim otrzymanie oficjalnego zezwolenia władz na jego wzniesienie. Wynikało to z konsekwentnej polityki rusyfikacyjnej władz carskich wobec Polaków. Jej apogeum nastąpiło po klęsce dwóch polskich powstań narodowych. Po upadku powstania listopadowego zamknięto np. Uniwersytet Wileński i Liceum Krzemienieckie, co było konsekwencją udziału studentów i nauczycieli w powstaniu. W latach 1832-1834 na mocy decyzji cara Mikołaja I z terenów Wołynia i Podola zostało wysiedlonych w głąb Rosji kilkanaście tysięcy polskich rodzin. W 1839 roku zlikwidowano kościół unicki, a księża i wierni siłą zosta-

${ }^{19}$ A. Kijas, Polacy na Uniwersytecie Charkowskim 1805-1917, Poznań 2008, s. 215.

${ }^{20}$ Mądzik, Korzeniowski, Latawiec, Tarasiuk, Polacy na wschodniej Ukrainie, s. 15.

${ }^{21}$ Z. Łukawski, Ludność polska w Rosji 1863-1914, Wrocław-Warszawa-Kraków 1978, s. 53. 
li zmuszeni do przejścia na prawosławie ${ }^{22}$. Po klęsce powstania styczniowego, w 1864 roku został ogłoszony zakaz budowy i remontu obiektów sakralnych bez zgody władz administracyjnych. Na budowę nowego kościoła musiał wydać zgodę Minister Spraw Wewnętrznych, a na remont starego - miejscowy gubernator. Jednak władze carskie $\mathrm{z}$ reguły bardzo rzadko wydawały stosowne zezwolenia ${ }^{23}$.

Pierwsze kościoły na Ukrainie Lewobrzeżnej zostały zbudowane przed wydaniem w 1864 roku wspomnianego wyżej rozporządzenia. W Charkowie katolicy obrządku łacińskiego początkowo użytkowali dwupiętrowego budynku stojącego koło zboru protestanckiego. Gromadzili się w nim na msze św. i nabożeństwa. Po przebudowie, która nadała budynkowi architekturę sakralną, świątynia stała się pierwszym kościołem dla katolików Charkowa ${ }^{24}$. Konsekracja kościoła odbyła się 1 listopada 1832 roku. Nadano mu wezwanie Matki Bożej Różańcowejej. Właśnie od tej daty, jak pisze Michał Żur, rozpoczęła się działalność parafii rzymskokatolickiej w Charkowie ${ }^{26}$.

Parafii charkowskiej szybko przybywało nowych wiernych. W 1886 roku obejmowała ona blisko 3000 wiernych oraz 1500 wojskowych katolików. Dotychczasowy kościół był za mały dla rosnącej liczebnie katolickiej wspólnoty, dlatego miejscowi Polacy podjęli decyzję o budowie większej świątyni ${ }^{27}$. Architektem nowego kościoła był Bolesław Michałowski ${ }^{28}$. Publicznie zadeklarował podczas posiedzenia rady parafialnej, że nie tylko bezpłatnie wykona projekt świątyni, ale i pokieruje pracami budowlanymi. Jako wyraz wdzięczności po zakończeniu budowy otrzymał od parafian 500 rubli. Budowę kościoła prowadzono w latach 1887-1891 (ulica Gogola 4) ${ }^{29}$. Osobliwością świątyni wybudowanej w stylu neogotyckim są jej sklepienia. Ponieważ nawa okazała się zbyt szeroka, aby można było założyć nad nią murowane sklepienia, wykonano żelazny szkielet - łuki, spięte odpowiednimi łączami, na nich zaś wymurowano wysklepki

${ }^{22}$ Żwanko, Polacy na Ukrainie Lewobrzeżnej, s. 23.

${ }^{23}$ I. Lisewicz, Duchowno spragli: Duchowne zittja polskoj nacionalnoj menszini na Naddniprjanskij Ukraini w 1864-1917 rr., Kijów 1997, s. 175; І. Лісевич, Духовно спраглі: Духовне життя польської національної меншини на Наддніпрянській Україні в 1864-1917 рр., Київ 1997 , c. 175.

${ }^{24}$ М. Жур, История римо-католической церкви в Харькове, s. 9.

${ }^{25}$ Ф. Рейнгардт, Римско-Католическая иерковь в Харькове, с. 261.

26 Жур, Історія римсько-католииької парафії в Харкові, https://catholic-kharkiv.org/ yeparhiya/istoriya/istoriya-rimsko-katolitskoyi-parafiyi-v-harkovi/ (dostęp: 20.05.2017).

27 Жур, История римо-католической церкви в Харькове, w: Polska diaspora w Charkowie. Historia i wspótczesność, Харків 2014, s. 130-131.

${ }^{28}$ Bolesław Michałowski (1830-1909) - architekt, inżynier miejski, wykładowca, działacz społeczny, aktywny uczestnik życia kulturalnego Polonii Charkowa. Charkowski okres życia (18741909) - to rozkwit talentu architekta; zaprojektował i odnowił wiele budynków - kilkanaście z nich jest zabytkami architektury. Jest jednym z założycieli Charkowskiego Oddziału Cesarskiego Rosyjskiego Towarzystwa Technicznego. Jego budynki charkowskie w stylu eklektycznym są unikalnym zjawiskiem w architekturze miasta drugiej połowy XIX i początku XX w. L. Żwanko, Wybitni Polacy i Charków: słownik biograficzny (1805-1918), thum. T. Dowżok, Charków 2019, s. 138.

${ }^{29}$ L. Żwanko, Polscy architeci Charkowa - Bolesław Michałowski i Marian Józef Zdzisław Charmański: szkic o życiu i tworczości, „Studio Architektury Nowoczesnej”, (2018) nr 6, s. 50. 
z mocno wypalonej cegły. Szkielet ten stanowi całkiem udaną imitację sklepienia, harmonizując $\mathrm{z}$ ogólnym stylem budowli. Wewnątrz kościoła znalazły się trzy ołtarze: główny - Niepokalanego Poczęcia Najświętszej Maryi Panny i dwa boczne - Jezusa Chrystusa, z obrazem Henryka Siemiradzkiego, oraz św. Antoniego ${ }^{30}$. W maju 1901 roku dzięki inżynierom Adamowi Krzyżanowskiemu i Adolfowi Pawłowiczowi, działaczom polskiej wspólnoty, w kościele założono oświetlenie elektryczne ${ }^{31}$.

Od początku lat 30. XX wieku władze sowieckiej Ukrainy zaczęły prześladować Kościół katolicki. Lokalni urzędnicy zamykali świątynie na „prośbę” obywateli, którzy postulowali przekształcenie ich w domy kultury lub w inne instytucje prowadzące świecką działalnośćc ${ }^{32}$. Dodatkowo skazywano na kary pieniężne i więzienia księży oraz parafian stających w ich obronie. Wzrastała również surowość wyroków w sprawach związanych z kultem religijnym, co wskazywało na totalną walkę władz sowieckich z Kościołem katolickim ${ }^{33}$. W 1937 roku ostatni proboszcz kościoła w Charkowie ks. Leonard Gaszyński został rozstrzelany, a świątynia zamknięta ${ }^{34}$.

W 1947 roku władze przekazały budynek kościoła obwodowej dyrekcji filmowej. W 1991 roku świątynia wróciła do katolików. Od 2002 roku jest katedrą pw. Wniebowzięcia Najświętszej Maryi Panny diecezji charkowsko-zaporowskiej. Aktualnie światynia jest centrum życia religijnego katolików i ośrodkiem skupiającym miejscową Polonię. Budynek jest także perłą stylu neogotyckiego i zabytkiem architektury sakralnej ${ }^{35}$.

Kolejny kościół na terenie guberni charkowskiej powstał w 1911 roku, w powiatowym mieście Sumy. Był to kościół filialny świątyni charkowskiej. Został on ustanowiony w związku ze wzrostem liczby katolików, z których większość była Polakami ${ }^{36}$. W latach 90. XIX wieku filantrop i przemysłowiec Paweł Charitonenko podarował działkę pod budowę kościoła katolickiego Niemcom, Polakom i Czechom, pracownikom swojego przedsiębiorstwa. Oprócz tego udzielił także stosownej pomocy finansowej. W 1900 roku miejscowe władze państwowe wydały pozwolenie na budowę kościoła, która rozpoczęła się w 1901 roku, ale z powodu trudności finansowych została ukończona dopiero dziesięć lat później37. Kościół został konsekrowany przez biskupa mohylewskiego Jana Cieplaka jako świątynia filialna katedry pw. Wniebowzięcia Najświętszej Maryi Panny w Charkowie.

30 Є. Зайонц, Невідомі джерела історії периої польської римо-католицької парафії у Харкові, w: Вісник Харківського національного університету імені В.Н. Каразіна, Серія Філологія 2016, s. 318.

${ }^{31}$ Lipiński, Polacy w Charkowie, s. 104.

32 Рубльова, Антикостьольна кампанія в УСРР: причини, інструментарій, перебіг (кінець 20-х - 30-ті рр.), с. 398.

33 Рубльова, Передмова, с. 44.

34 Tamże, c. 46.

35 Жванко, Spuścizna architektów Polaków na mapie Charkowa, c. 183.

${ }^{36}$ Mądzik, Korzeniowski, Latawiec, Tarasiuk, Polacy na wschodniej Ukrainie, s. 106.

${ }^{37}$ Католицькому храму в Сумах більше ста років, http://www.websu.info/archives/3754 (dostęp: 26.12.2019). 
Kościół filialny w Sumach pw. Zwiastowania Najświętszej Maryi Panny jest niewielką świątynią z elementami stylu gotyckiego i romańskiego. Zbudowano go z czerwonej cegły. Budynek ma wysoki i spadzisty dach. Ściany boczne posiadają pilastry i strzeliste okna. Nad głównym wejściem znajduje się portal nawiązujący do wzorów średniowiecznych, a nad nim znajduje się okno - rozeta. Na dziedzińcu świątyni umieszczono niewielką rzeźbę Matki Bożejej ${ }^{38}$.

W 1930 roku „na prośbę obywateli radzieckich” kościół w Sumach został zamknięty ${ }^{39}$. Budynek wykorzystywano jako obwodowe muzeum krajoznawcze, hala sportowa Instytutu Pedagogicznego, a nawet jako oddział miejscowego KGB. Dopiero w maju 1994 roku został zwrócony wiernym ${ }^{40}$. Dzisiaj wspólnota wiernych gromadząca się w kościele prowadzi różnorodne działania związane zarówno z życiem religijnym, jak i społecznym ${ }^{41}$.

Na terenie guberni czernihowskiej zbudowano dwa kościoły, choć liczba mieszkających tam Polaków nie była zbyt duża. Pod koniec XIX wieku zgodnie ze spisem powszechnym Imperium Rosyjskiego (1897) w Czernihowie mieszkało 374 Polaków. W Nieżynie, drugim mieście guberni czernihowskiej pod względem liczby mieszkańców, zarejestrowano 238 Polaków $^{42}$.

Również w przypadku budowy kościoła w Czernihowie istnieją rozbieżności w ustaleniu daty jego powstania. Według jednej wersji, wskazanej w książce $P o-$ lacy na wschodniej Ukrainie w latach 1832-1921, „Swiątynia katolicka w Czernihowie została zbudowana w 1838 roku"43. Również na stronie internetowej Kościoły i kaplice Ukrainy zaznaczono, że „w 1838 r. na koszt parafian wybudowano kościół w Czernihowie" ${ }^{4}$. Inne źródło wskazuje natomiast datę o 20 lat późniejszą:

W 1858 roku w Chernihowie (obiecnie - na rogu ulic Piatnickiej i Czernyszewskiego), powstał kościół Wniebowzięcia Najświętszej Maryi Panny i świętego Jana (Joanna) Chrzciciela ${ }^{45}$.

W czasach sowieckich świątynia została zamknięta, a pobliski cmentarz katolicki zniszczony. Na miejscu nekropolii, na której w 1865 roku pochowano Ewelinę Korzeniowską, matkę światowej sławy pisarza Józefa Konrada Korzeniow-

38 Костел Благовіщення Пресвятої Діви Марї, https://ua.igotoworld.com/ua/poi_object/71473_kostel-blagovescheniya-presvyatoy-devy-marii.htm (dostęp: 26.12.2019).

${ }^{39}$ Рубльова, Антикостьольна кампанія в УСРР: причини, інструментарій, перебіг (кінець 20-x-30-mi pp.), c. 398.

${ }^{40}$ Костел Благовіщення Пресвятої Діви Марії (Суми), https://uk.wikipedia.org/wiki/ (dostęp: 26.12.2019).

${ }^{41}$ Католицькому храму в Сумах більше ста років, http://www.websu.info/archives/3754 (dostęp: 26.12.2019).

${ }^{42}$ О. Іванюк, Етнічний склад міського населення Чернігівської губернії наприкінці XIX cm. за матеріалами опублікованих статистичних документів Російської імперї, с. 117.

${ }^{43}$ Mądzik, Korzeniowski, Latawiec, Tarasiuk, Polacy na wschodniej Ukrainie, s. 106.

${ }^{44}$ Костели і каплиці України, http://rkc.in.ua/index.php?\&m=k\&f=akzcg_\&p=cg_cgud\&l=u (dostęp: 29.12.2019).

${ }^{45} \mathrm{O}$. Ясенчук, Чернігів польський: итрихи до етнічного портрету міста, http://pivnich. info/chernihiv-polskyj-shtryhy-do-etnichnoho-portretu-mista/ (dostęp: 21.12.2019). 
skiego, postawiono budynek mieszkalny dla kierownictwa władz obwodowych oraz budynek obwodowego komitetu partii komunistycznej. Aktualnie gmach dawnego kościoła jest zajmowany przez Archiwum Państwowe obwodu czernihowskiego. W latach 1992-1993 miejscowa wspólnota katolicka bezskutecznie podejmowała starania o zwrot budynku kościoła. Ostatecznie w 2002 roku rozpoczęto budowę nowej świątyni ${ }^{46}$ pw. Zesłania Ducha Świętego, która została konsekrowana w $2015 \mathrm{roku}^{47}$.

W Nieżynie, miasteczku guberni czernihowskiej, kościół pw. śś. Piotra i Pawła został zbudowany w końcu XIX wieku ${ }^{48}$. Świątynia rzymskokatolicka powstała staraniami nielicznej, ale hojnej polskiej wspólnoty. Na rzecz kościoła w Nieżynie duże sumy pieniężne w połowie lat 90 . XIX w. przeznaczyli m.in. Fryderyka Artypowa oraz kapitan Włodzimierz Kwilecki ${ }^{49}$. Po wprowadzeniu władzy sowieckiej działalność parafii został sparaliżowana, ponieważ aresztowano duszpasterzy, kościół zamknięto, by ostatecznie w 1948 roku go zburzyćc ${ }^{50}$. Według innych źródeł świątynia została spalona w 1943 roku podczas odwrotu wojsk niemieckich ${ }^{51}$. Aktualnie funkcjonujący kościół został wybudowany 2008 roku $^{52}$.

W guberni połtawskiej zbudowano trzy kościoły (Połtawa, Romny i Krzemieńczuk). Świątynia w Połtawie powstała na podstawie projektu pomocnika architekta gubernialnego Łuka Semko-Sawojskiego ${ }^{53}$. Plan został pozytywnie zatwierdzony w dniu 23 czerwca 1852 roku przez gubernialną komisję budownictwa i dróg gdyż ,(...) uznano go za wykonany zgodnie z zasadami architektury"s4. Projekt przewidywał budowę świątyni o jednej nawie, w formie rzymskiej bazyliki. Budynek miał mieć wysoki cokół, ze spadzistym dachem w stylu późnego klasycyzmu ${ }^{55}$. Narożniki otwartego frontonu, ozdobione arkadowym pasem, miały być podtrzymywane przez potrójne wklęsłe pilastry z kapitelami korynckimi.

46 Чернігів. Костел Успіння Пресвятої Діви Марії та св. Йоана Хрестителя, http://rkc.in. ua/index.php? $1=\mathrm{r} \& \mathrm{~m}=\mathrm{k} \& \mathrm{f}=\mathrm{occg} \_\& \mathrm{p}=\mathrm{cg} \_$cgud (dostęp: 21.12.2019).

47 Чернігів. Костел Зіслання Святого Духа, http://www.rkc.in.ua/index.php?\&m=k\&f=akzc$\mathrm{g} \_\& \mathrm{p}=\mathrm{cg} \_\operatorname{cgsd} \& \mathrm{l}=\mathrm{u}(\mathrm{dostęp}: 29.12 .2019)$.

${ }^{48}$ Храм Петра і Павла (Ніжин), https://uk.wikipedia.org/wiki/ (dostęp: 23.12.2019).

${ }^{49}$ Mądzik, Korzeniowski, Latawiec, Tarasiuk, Polacy na wschodniej Ukrainie, s. 107.

${ }^{50}$ Храм Петра і Павла (Ніжин), https://uk.wikipedia.org/wiki/ (dostęp: 23.12.2019).

${ }^{51}$ Костьол Святих Петра і Павла, https://nizhyn-travel.com.ua/uk/pages/47-kostol_svyatyx_ petra_i_pavla (dostęp: 26.12.2019).

${ }^{52}$ Храм Петра і Павла (Ніжин), https://uk.wikipedia.org/wiki/ (dostęp: 23.12.2019).

${ }^{53}$ Łuka Semko-Sawojski (1830-1887) - architekt. Po ukończeniu Szkoły Budownictwa w Petersburgu (1851) został skierowany do Połtawy. Najpierw pracował jako asystent architektoniczny w Komisji Budownictwa i Dróg guberni połtawskiej, w 1862 roku - architekt miejski Połtawy, a w następnym roku - architekt wspomnianej Komisji, od 1865 roku pełnił funkcję młodszego architekta guberni połtawskiej. W 1878 roku został przeniesiony na stanowisko inżyniera guberni Besarabskiej. W 1884 roku przeszedł na emeryturę. Лука Назарович Семко-Савойський, https:// uk.wikipedia.org/wiki/\% (dostęp: 8.01.2020).

${ }^{54}$ Трегубов, Римо-католииький Хрестоздвиженський костьол в Полтаві, http://histpol. pl.ua/ru/ pamyatniki-istorii-i-arkhitektury/religioznye-sooruzheniya?id=7925 (dostęp: 24.12.2019).

55 Бєлявська, Архітектура полтавських храмів пореформеної доби, https://archcity. pro/2017/10/16/arhitektura-poltavskyh-hramiv-poreformenoyi-doby/ (dostęp: 24.12.2019). 
Drzwi główne otaczał niewielki portal z dwuspadowym frontonem. Obok drzwi umieszczono dwa okna z podwójnymi łukami ozdobione korynckimi półkolumnami. Nad portalem wejściowym miało być duże okrągłe okno z rozetą. Kościół miał mieć $24 \mathrm{~m}$ długości, $12 \mathrm{~m}$ szerokości i nieco ponad $14 \mathrm{~m}$ wysokości ${ }^{56}$.

Kamień węgielny pod budowę nowego kościoła wmurowano 27 września 1852 roku na placu, który znajdował się na rogu ulic Nowosadowej i Stritenskoj. Budowa świątyni trwała prawie siedem lat, konsekrowano ją dopiero 12 czerwca 1859 roku. Przeciągające się prace budowlane wynikały m.in. ze zmian w projekcie architektonicznym kościoła. Powstająca świątynia była wyższa i węższa w stosunku do pierwotnych planów. Powiększenie portalu spowodowało usunięcie dwóch okien. W miejscu okna rozety, w niewielkiej niszy ściany umieszczono łacińskie wezwanie GLORIA IN EXCELSIS DEO. Zmieniła się także dekoracja fasad bocznych: podwójne okna zostały zastąpione pojedynczymi. Być może korekty w planie architektonicznym budowy kościoła wynikały z okresowych braków środków na budowę świątyni. Powstający kościół pw. Krzyża Świętego był bowiem finansowany na bieżąco tylko przez miejscową wspólnotę katolicką ${ }^{57}$.

W 1931 roku na prośbę mieszkańców miasta kościół w Połtawie został „samo zlikwidowany"58. Ostatecznie zamknięto go w 1936 roku. W następnym roku, podobnie jak większości świątyń chrześcijańskich w Połtawie, został zburzony, a cegły wykorzystano na inne cele budowlane. W późniejszym czasie na miejscu byłego kościoła zbudowano szkołę medyczną ${ }^{59}$.

W miasteczku Romny na początku XX wieku wybudowano kościół pw. Niepokalanego Poczęcia Najświętszej Maryi Panny według projektu inżyniera Jasnowskiego $^{60}$. Powodem wzniesienia świątyni był wzrost liczby Polaków zamieszkujących miasteczko i okolice. W ostatnich dwóch dekadach XIX wieku Polacy stworzyli prężną społeczność w Romnach. Po otrzymaniu zgody władz państwowych wznieśli kościół. Po upływie dwunastu lat katolicy w Romnach posiadali własną parafię, której proboszczem był ks. Stanisław Dombrowski (Dąbrowski), katecheta miejscowego gimnazjum. Liczyła ona ok. 1000 wiernych ${ }^{61}$.

Kościół w Romnach był zbudowany w stylu romańskim, z elementami klasycyzmu. Jego bryła wyróżniała się w otaczającej go przestrzeni miejskiej. Była to prostokątna kamienna budowla o czterech prostokątnych kolumnach po bokach głównych drzwi wejściowych. Nad drzwiami umieszczona była stiukowa listwa i okno z rozetą. Od strony dziedzińca budowla miała półkolisty kształt. Z lewej strony kościoła wybudowano wysoką kamienną dzwonnicę. Plac kościelny był

${ }^{56}$ Трегубов, Римо-католицький Хрестоздвиженський костьол в Полтаві, http://histpol. pl.ua/ru/ pamyatniki-istorii-i-arkhitektury/religioznye-sooruzheniya?id=7925 (dostęp: 24.12.2019).

${ }^{57}$ Хрестоздвиженський костел (Полтава), https://uk.wikipedia.org/wiki/(dostęp: 22.12.2019).

${ }_{58}$ Рубльова, Антикостьольна кампанія в УСРР: причини, інструментарій, перебіг (кінеиь 20-x-30-mi pp.), с. 398.

${ }_{59}$ Трегубов, Римо-католищький Хрестоздвиженський костьол в Полтаві http://histpol. pl.ua/ru/ pamyatniki-istorii-i-arkhitektury/religioznye-sooruzheniya?id=7925 (dostęp: 24.12.2019).

${ }^{60}$ Костел Непорочного Зачаття Пресвятої Діви Марії (Ромни), https://uk.wikipedia.org/ wiki/ (dostęp: 8.01.2019).

${ }^{61}$ Mądzik, Korzeniowski, Latawiec, Tarasiuk, Polacy na wschodniej Ukrainie, s. 107. 
opasany metalowym ogrodzeniem przypominającym wiklinę, które wspierało się na ceglanych słupach. W 1910 roku świątynie konsekrował biskup mohylewski Jan Cieplak. W 1932 roku kościół w Romnach został zamknięty przez władze sowieckie, a cały majątek parafii skonfiskowano ${ }^{62}$. Zburzono wówczas dzwonnicę ${ }^{63}$. Przez pewien czas w budynku kościoła mieściły się warsztaty miejscowej szkoły politechnicznej. W 1999 roku, w przeddzień Bożego Narodzenia, drugie piętro budynku zostało przekazane miejscowym katolikom. Z czasem parafianie odzyskali wszystkie pomieszczenia kościoła i przykościelne budynki gospodar$\mathrm{cze}^{64}$. Rewindykacja mienia kościelnego była możliwa dzięki podpisaniu w dniu 26 kwietnia 2002 roku przez premiera Ukrainy Anatolija Kinacha rozporządzenia Gabinetu Ministrów Ukrainy „W sprawie przekazania wspólnocie religijnej Kościoła rzymskokatolickiego budynku byłego kościoła rzymskokatolickiego"65.

Według spisu powszechnego Imperium Rosyjskiego (1897) w powiatowym mieście Krzemieńczuk mieszkało ok. 1204 katolików. Jednak kościół wybudowano dopiero w 1910 roku. „Piękny kościół św. Józefa w stylu gotyckim z organami był wzniesiony na koszt dobroczyńcy pani Grabiny Kotowskiej z Połtawy" ${ }^{\prime 66}$ oraz dzięki hojności członków miejscowej polskiej kolonii. Warto odnotować, że warunki, w których powstała świątynia, były dość trudne:

W Krzemieńczuku nad Dnieprem, kresowem mieście archidiecezji mohylowskiej, gdyż po drugiej już stronie Dniepru łączą się w tem miejscu djecezje łucko-żytomierska i tyraspolska, mieszka znaczna liczba katolików. Krzemieńczuk należy do parafii połtawskiej, nie ma tu jednakże stałego domu Bożego: służba Boża odprawia się przez księdza, dojeżdżającego z Połtawy - zazwyczaj co drugi tydzień - w prowizorycznie po domach prywatnych urządzanych kaplicach. Podobno katolicy kremieńczugscy krzątają się energicznie około urządzenia stałego domu Bożego. Ze względu na rozrastające się ciągle handlowe miasto i, co za tem idzie, na rosnącą wciąż w mieście liczbę katolików, stały kościół w Kremieńczugu jest nieodzownie potrzebny. Nie wątpimy, że obecny proboszcz połtawski (w chwili gdy to piszemy ks. Borzdzyński) zajmie się gorliwie przeprowadzeniem tej sprawy. Plany budowy własnego kościoła w Krzemieńczuku stały się bardziej realne z chwilą pojawienia się możliwości finansowych. (...) jeden z Polaków, niejaki Sokołowski, pracujący na obszarze guberni połtawskiej, wniósł ofiarę na budowę w tym mieście kaplicy katolickiej. Społeczność katolicka w pierwszej dekadzie XX wieku uzyskała

\footnotetext{
${ }^{62}$ Рубльова, Антикостьольна кампанія в УСРР: причини, інструментарій, перебіг (кінець 20-x-30-mi pp.), c. 399.

${ }^{63}$ Костел Непорочного Зачаття Пресвятої Діви Марії (Ромни), https://uk.wikipedia.org/ wiki/ (dostęp: 8.01.2019).

${ }^{64}$ Ромни. Костел Непорочного Зачаття Пресвятої Діви Марї, http://www.rkc.in.ua/index. $\mathrm{php} ? \& \mathrm{~m}=\mathrm{k} \& \mathrm{f}=\mathrm{ossuro} \& \mathrm{p}=$ suroronz $\& \mathrm{l}=\mathrm{u}($ dostęp: 8.01.2019).

${ }_{65}^{65}$ Костел Непорочного Зачаття Пресвятої Діви Марї (Ромни), https://uk.wikipedia.org/ wiki/ (dostęp: 8.01.2019).

${ }_{66}$ Римсько-католицька парафія у Кременчуиі, https://www.05366.com.ua/news/674415/ rimsko-katolicka-parafia-u-kremencuci (dostęp: 24.12.2019).
} 
kolejny zastrzyk finansowy. Szlachcianka narodowości polskiej nazwiskiem Kotowicz zapisała w swoim testamencie kilkadziesiąt tysięcy rubli na rzecz budowy świątyni dla miejscowych katolików ${ }^{67}$.

W 1919 roku kościół został odebrany przez władzę sowiecką miejscowym katolikom i przekazany na świecką działalnośćc ${ }^{8}$. W budynku znajdowały się: Dom Kultury Sanitarnej, kino oraz dziecięca szkoła sportowa. W latach 90. XX wieku kościół został przekazany Ukraińskiej Cerkwi Prawosławnej Patriarchatu Kijowskiego. Odtąd budynek pełni funkcję cerkwi pw. św. Mikołaja ${ }^{69}$. Od 2008 roku katolicy w Krzemieńczuku korzystają z nowo wybudowanego kościoła franciszkanów pw. św. Józefa ${ }^{70}$.

W guberni jekaterynosławskiej zbudowano pięć kościołów: w Jekaterynosławiu, Kamieńskom, Mariupolu, Jenakijewie i Bachmucie. Pierwsza świątynia pw. Wniebowzięcia Najświętszej Maryi Panny - w miasteczku Mariupol powstała w 1860 roku $^{71}$. Kościół wybudowano dzięki „najwyższej” aprobacie (после „высочайшего” утверждения) cara Mikołaja I z dnia 15 listopada 1853 roku. Budynek wznoszono prawie siedem lat, a pierwsze nabożeństwo odprawiono w kościele dopiero 18 października 1860 roku. Świątynia znajdowała się na rogu ulic Targowej i Italijskiej (Włoskiej). W jej budowie wziął udział młody Archip Kuindży, który w przyszłości stanie się znanym rosyjskim malarzem i grafikiem ${ }^{72}$. Tak o przebiegu historii powstania kościoła piszą polscy badacze:

Stosunkowo wcześnie podjęto starania o stworzenie samodzielnej parafi i w Mariupolu. Ponadto pojawiła się idea budowy wolno stojącej świątyni rzymskokatolickiej. Już w 1833 roku udało się wydzielić grunt pod przyszłą inwestycję. Wydawało się, że realizacja projektu potoczy się bardzo szybko. Na przeszkodzie jednak stanął brak odpowiednich środków finansowych i stosunkowo niewielka liczba potencjalnych parafian. Budowę rozpoczęto w 1842 roku, lecz wstrzymano ją po siedmiu latach. W 1853 roku udało się otrzymać kilka tysięcy rubli dotacji z Głównego Zarządu Dróg Komunikacyjnych. To pozwoliło wznowić budowę. Ponadto swój udział w budowie kościoła w Mariupolu miał rząd włoski. Inwestycję budowlaną zakończono ostatecznie w 1860 roku. Parafia mariupolska liczyła stosunkowo niewielu wiernych ${ }^{73}$.

${ }^{67}$ M. Mądzik, M. Korzeniowski, K. Latawiec, D. Tarasiuk, Polacy na wschodniej Ukrainie w latach 1832-1921, Lublin 2014. s. 110.

${ }^{68}$ Iсторія собору, http://cmcobor.in.ua/page/storja-soboru (dostęp: 23.12.2019).

${ }^{69}$ Кременчук. Костел св. Йосифа (старий), http://rkc.in.ua/index.php?\&m=k\&f=ahzpo \&p=po krks\&l=u (dostęp: 24.12.2019).

${ }^{70}$ Кременчук. Костел св. Йосифа, http://rkc.in.ua/index.php?\&m=k\&f=ahzpo _\&p=po_ krks\&l=u (dostęp: 24.12.2019).

${ }^{71}$ Маріуполь (Домаха, Павловськ, Жданов). Костел Успіння Пресвятої Діви Марії, http:// rkc.in.ua/index.php? $1=\mathrm{u} \& \mathrm{~m}=\mathrm{k} \& \mathrm{f}=\mathrm{osdo} \_\& \mathrm{p}=\mathrm{do} \_$mpud (dostęp: 24.04.2017).

${ }^{72}$ Утраченные храмы Мариуполя, https://ru.wikipedia.org/wiki/ (dostęp: 26.12.2019).

${ }^{73}$ Mądzik, Korzeniowski, Latawiec, Tarasiuk, Polacy na wschodniej Ukrainie, s. 109. 
W 1933 roku kościół został zamknięty przez władze sowieckie ${ }^{74}$ i wkrótce wysadzono go w powietrze ${ }^{75}$. $\mathrm{Z}$ czasem na jego miejscu wybudowano gmach, w którym aktualnie funkcjonuje przedszkole ${ }^{76}$.

W Jekaterynosławiu już w 1842 roku miejscowa społeczność katolicka skierowała prośbę do władz o zgodę na budowę kościoła. Jednak dopiero po powstaniu diecezji tyraspolskiej z siedzibą w Saratowie ponownie rozpoczęto starania o budowę kościoła ${ }^{77}$. Według Olgi Bakowieckiej 4 września 1859 roku biskup tyraspolski Ferdynand Kahn otrzymał list od jekaterynosławskiego generał-gubernatora z decyzją Departamentu Spraw Duchowych Wyznania Zagranicznego w sprawie budowy kościoła rzymskokatolickiego w Jekaterynosławiu. Jednak pozwolenie to było wydane jeszcze 11 maja $1844 \mathrm{roku}^{78}$. Duże trudności napotykało również utworzenie parafii katolickiej w mieście.

Ministerstwo Spraw Wewnętrznych bardzo długo nie wyrażało zgody na utworzenie w Jekaterynosławiu samodzielnej parafii. Decydując się na utworzenie samodzielnej parafi i w Jekaterynosławiu, władze carskie zgodziły się na utworzenie etatu wikariusza. Wpływ na to miał fakt bardzo licznej rzeszy wyznawców Kościoła rzymskokatolickiego w Jekaterynosławiu i okolicach ${ }^{79}$.

Działka ziemi pod budowę kościoła została nabyta przy prospekcie Jekaterinienskiego na terenach miejskiego „górnego” ogrodu ${ }^{80}$. Projekt kościoła został wykonany przez dwóch architektów: - najpierw przez Alberta Brodnickiego ${ }^{81}$, a następnie przez Piotra Merkułowa. Świątynię wybudowano w latach 1869$1877^{82}$. Niewielki kościół w stylu gotyckim był tradycyjny architektonicznie, ale równocześnie zwierał w sobie nowe inspiracje. Fronton świątyni od strony ulicy był ozdobiony dwoma wysokimi wieżami, w których umieszczono dzwony. Nad głównym wejściem był portal, a nad nawą ustawiono figurę anioła z krzyżem. Ze względu na małą liczbę wiernych świątynia miała tylko jedną nawę oświetloną wysokimi, strzelistymi oknami, zakończoną absydą ołtarzową. Nad ołtarzem na dachu była przewidywana wysoka ażurowa wieża.

${ }^{74}$ Рубльова, Антикостьольна кампанія в УСРР: причини, інструментарій, перебіг (кінець 20-x-30-mi pp.), c. 399.

${ }^{75}$ Маріуполь (Домаха, Павловськ, Жданов). Костел Успіння Пресвятої Діви Марії, http:// rkc.in.ua/index.php? $1=\mathrm{u} \& \mathrm{~m}=\mathrm{k} \& \mathrm{f}=\mathrm{osdo} \_\& \mathrm{p}=\mathrm{do} \_\mathrm{mpud}$

${ }^{76}$ Утраченные храмы Мариуполя, https://ru.wikipedia.org/wiki/ (dostęp: 26.12.2019).

${ }^{77}$ Баковецька, Римо-католицьька иерква в Украйні в кінці XVIII - XIX столітті, с. 218.

${ }^{78}$ Tamże, c. 219.

${ }^{79}$ Mądzik, Korzeniowski, Latawiec, Tarasiuk, Polacy na wschodniej Ukrainie, s. 112.

${ }^{80}$ Старостин, Римско-католический костел в Екатеринославе. Храм Св. Йосипа, https:// www. shukach.com/ru/node/889 (dostęp: 24.12.2019).

${ }^{81}$ Albert Brodnicki (1830-?) - inżynier cywilny. Po ukończeniu Szkoły Budownictwa w Petersburgu (1852) pracował jako asystent architekta w Komisji Budownictwa i Dróg guberni jekaterynosławskiej. W ciągu lat 60. XIX wieku pełnił obowiązki architekta gubernialnego, w latach 1865-1875 był głównym architektem gubernialnym. Zaprojektował wiele licznych budynków w Jekaterynoslawiu i na obszarze guberni, niektóre są zabytkami architektury. Зодчi, інженери, художники, що брали участь у формуванні Катеринослава, http://forum.cebos.com.ua/viewtopic. php? $\mathrm{f}=2 \& \mathrm{t}=126$ (dostęp: 8.01.2020).

${ }^{82}$ Żwanko, Polacy na Ukrainie Lewobrzeżnej, s. 38. 
Pierwotny projekt kościoła autorstwa A. Brodnickiego po przedstawieniu go Komitetowi Techniczno-Budowlanemu Ministerstwa Spraw Wewnętrznych nie został zatwierdzony. Oprócz wątpliwości dotyczących architektury kościoła pojawiły się poważne zastrzeżenia do wytrzymałości konstrukcji przyszłego budynku. W rezultacie projekt został znacznie zmieniony przez członka Komitetu, architekta Piotra Merkulowa. Zwiększono nieznacznie szerokość kościoła, natomiast zmniejszono wysokość wież dzwonnicy (całkowita wysokość wraz z iglicami pozostała niezmieniona). Zmniejszono również wysokość nawy. Zmieniono także dekorację fasady kościoła, znacznie ją uproszczając, przez co była ona zbliżona do stylu romańskiego. W dniu 16 lipca 1869 roku nowy projekt architektoniczny kościoła w Jekaterynosławiu został zatwierdzony przez Ministerstwo Spraw Wewnętrznych ${ }^{83}$. Budowę kościoła pw. św. Józefa rozpoczęto 17 czerwca 1872 roku ${ }^{84}$, ukończono w 1877 roku, a konsekrowano w 1878 roku $^{85}$.

Dla ówczesnej architektury prowincjonalnego Jekaterynosławia architektura kościoła była dość niezwykła. Wśród dwupiętrowych budynków wyrosła potężna budowla, a jego dwie masywne strzeliste wieże były widoczne w odległości kilku kwartałów. Kościół od razu stał się centrum życia wspólnoty polskiej, a także skupił miejscowych katolików różnych narodowości ${ }^{86}$.

Liczba katolików w mieście stale rosła, dlatego konieczna stała się rozbudowa świątyni. W dniu 22 lutego1900 roku Ministerstwo Spraw Wewnętrznych zaaprobowało projekt rozbudowy kościoła autorstwa architekta gubernialnego Stanisława Charmańskiego. W ramach projektu budowla została rozszerzona o nawy boczne. Przebudowano również prezbiterium. Prace zakończono w 1910 roku.

Po nastaniu władzy sowieckiej w 1928 roku kościół został zamknięty. Początkowo mieścił się w nim warsztat szklarski, ale w połowie lat 30. XX wieku przekształcono go w halę wystawową, by w końcu przebudować go na halę sportową. Pomimo zmian wnętrza kościół na zewnątrz nie został przekształcony, usunięto jedynie krzyże z dachu ${ }^{87}$. Kościół powrócił do katolików w 2011 roku. Odtąd codziennie odprawiane są w nim msze św. mimo trwającego remontu wnętrza świątyni ${ }^{88}$.

Do parafii św. Józefa w Jekaterynosławiu należeli również katolicy z miasteczka Pawłograd. W latach 1896-1899 wzniesiono kamienną kaplicę ufudowaną przez notariusza Karla Gebda. W okresie władzy sowieckiej została ona zamknięta, a następnie użytkowana jako magazyn i sklep. W 1998 roku dzięki

\footnotetext{
${ }^{83}$ Старостин, Римско-католический костел в Екатеринославе. Храм Св. Йосипа, https:// www. shukach.com/ru/node/889 (dostęp: 24.12.2019).

${ }^{84}$ Баковецька, Римо-католицька церква в Украӥні в кінці XVIII - ХІХ столітті, с. 219.

${ }^{85}$ Старостин, Римско-католический костел в Екатеринославе. Храм Св. Йосипа, https:// www. shukach.com/ru/node/889 (dostęp: 24.12.2019).

${ }^{86}$ Константин Шруб, Люди Днепра: архитекторы Бродниикие, https:/gorod.dp. ua/ news/168079 (dostęp: 24.12.2019).

${ }^{87}$ Старостин, Римско-католический костел в Екатеринославе. Храм Св. Йосипа, https:// www. shukach.com/ru/node/889 (dostęp: 24.12.2019).

${ }^{88}$ Żwanko, Polacy na Ukrainie Lewobrzeżnej, s. 38.
} 
staraniom mieszkanki Pawłogradu Niny Pobiedymskiej budynek został zwrócony katolikom. W dniu 2 października 2010 roku odnowioną świątynię konsekrował biskup Marian Buczek ${ }^{89}$.

W miasteczku Kamieńskoje w guberni Jekaterynosławskiej budowę kościoła pw. św. Mikołaja rozpoczęto wmurowaniem kamienia węgielnego dnia 17 września 1895 roku. Prace zakończono w $1897 \mathrm{roku}^{90}$. Autorem projektu świątyni i kierownikiem budowy był architekt Marian Józef Charmański ${ }^{91}$. Został on zaangażowany przez Ignacego Jasiukowicza, dyrektora Zakładu Południowo-Rosyjskiego Dnieprowskiego Towarzystwa Metalurgicznego. Kościół powstał sumptem pracowników wspomnianego zakładu. Ich wpłaty pieniężne musiały być duże, skoro budowę świątyni ukończono w niecałe dwa lata. Dodatkowo tak szybkie tempo budowy wskazuje na owocną współpracę miejscowych Polaków wspartych przez lokalny przemysł nie tylko finansowo, ale i organizacyjnie. Inspiracją do budowy kościoła katolickiego był fakt, że

W ostatnich dwóch dekadach XIX stulecia parafia zyskiwała kolejne rzesze wiernych. Było to związane z rozbudową przemysłu na terenie guberni jekaterynosławskiej. Szczególna rola przypadła dość prężnie rozwijającej się kolonii polskiej w Kamieńsku².

Świątynia zbudowana była z żółtej cegły przywiezionej z Kijowa oraz wzorowana na gotyckiej katedrze-twierdzy z kontroforsami bocznych fasad i lukami okiennymi.

Monumentalna budowla $\mathrm{z}$ dwiema 33-metrowymi wieżami wzdłuż wschodniej fasady z lotu ptaka podobna do krzyża lacińskiego leżącego na ziemi. Szczególną uwagę $\mathrm{w}$ architektonicznym rozwiązaniu kościoła udzielono portalu głównemu z dwojgiem „gotyckich” drzwi. Nad głównym wejściem umieszczono łukowe okno, które przewyższa podwójne drzwi wejściowe. Cztery strzeliste i trzy okragge okna są wpisane w kontury tego ogromnego okna. Dwie wieży były zdobione wysokimi krzyżami z czarnego żelaza, które jakby się unosiły w niebie nad kościołem ${ }^{93}$.

Kościół pw. św. Mikołaja konsekrowano w dniu 25 września 1905 roku. Chociaż świątynia mogła pomieścić do 500 osób, zdarzało się, że z powodu przybycia

${ }^{89}$ Павлоград. Костел св. Архангела Михаӥла, http://www.rkc.in.ua/index.php?\&m=k\&f $=$ ahzdppg\&p=dppgpgmh\&l=r (dostęp: 15.02.2020).

${ }^{90}$ Слоневский, Жизнь. Смерть. Воскресение. Днепропетровск 2009, https://sobitie.com.ua/ istoriya/aleksandr-slonevskiy-kniga-zhizn-smert-voskresenie-chast-i-glavy-5-8 (dostęp: 18.02.2020).

${ }^{91}$ Marian Józef Zdzisław Charmański (1859-1924) - architekt, inżynier, działacz społeczny, wykładowca. Charkowski okres życia (1896-1919) to czas rozkwitu talentu architektonicznego i aktywna działalność jako inżynier gubernialny. Jeden z czołowych działaczy Polonii Charkowa: starosta Kościoła rzymskokatolickiego, współorganizator i członek Zarządu Domu Polskiego, autor projektu i kierownik budowy gmachu Polskiego Domu. W 1919 roku przed okupacją bolszewicką wyjechał do Warszawy. Sześć budynków z cechami ukraińskiego modernizmu to zabytki architektury. Żwanko, Wybitni Polacy i Charków: stownik biograficzny (1805-1918), s. 191.

${ }^{92}$ Mądzik, Korzeniowski, Latawiec, Tarasiuk, Polacy na wschodniej Ukrainie, s. 113

${ }_{93}^{93}$ Слоневский, Историческая загадка: кто был архитектором костёла Святого Николая?, https://stsergiydndz.wixsite.com/library/slonevsky-istoricheskaya-zagak (dostęp: 24.12.2019). 
większej liczby wiernych, część z nich musiała słuchać mszy św. na placu przykościelnym. Przy kościele funkcjonowała biblioteka dla parafian ${ }^{94}$.

W dniu 12 grudnia 1929 roku na podstawie decyzji miejscowych władz kościół w Kamieńskim został zamknięty. Aresztowano proboszcza ks. Jakuba Rosenbacha, którego zesłano na Wyspy Sołowieckie, gdzie w 1938 roku został rozstrzelany. W budynku kościoła władze otworzyły klub polski, a później mieściły się w nim: wojskowe biuro rekrutacyjne, filia Uniwersytetu Marksizmu-Leninizmu, planetarium, warsztaty artystyczne, magazyn firmy „Meble”, spółdzielnie i itp.

Na początku lat 90. XX wieku w Dnieprodzierżyńsku (dawne Kamieńskie) powstała „Grupa inicjatywna w sprawie odrodzenia kościoła”, wśród członków której nie było jednak żadnego katolika. W rezultacie jej działalności kościół został przywrócony społeczności katolickiej miasta. W dniu 30 listopada 1991 roku pod murami świątyni odprawiono pierwszą mszę św. ${ }^{95}$ Aktualnie kościół ten jest jednym z najpiękniejszych zabytków architektury neogotyckiej na Lewobrzeżu Ukrainy.

W miasteczku Jenakijewe budowę kościoła rozpoczęto w 1897 roku ufundowaną przez parafian belgijskiego i polskiego pochodzenia. Dzięki aktywnemu wsparciu finansowemu Juliana Potiera, dyrektora miejscowego zakładu przemysłowego, budowę świątyni ukończono w 1900 roku. Jednak prace związane z wykończeniem wnętrza i wyposażeniem kościoła trwały do 1906 roku. Odbyła się wówczas konsekracja świątyni pw. Podwyższenia Krzyża Świętego. Przed wybuchem rewolucji lutowej 1917 roku parafia liczyła ponad 2000 wiernych. Na początku lat 20. zeszłego stulecia władze sowieckie przekształciły kościół w zamknięty klub dla pracowników politycznych. Jednak dzięki o. Stanisławowi Wołskiemu, który wynajmował świątynię od władzy, nabożeństwa odbywały się aż do 1935 roku. Od lat 70. aż do końca lat 90. XX wieku w budynku kościoła działał klub sportowy ${ }^{96}$. Obecnie budynek świątyni jest użytkowany przez wiernych, jednak spotyka się to $\mathrm{z}$ problemami, gdyż miasto Jenakijewe znajduje się $\mathrm{w}$ strefie okupowanej przez prorosyjskich separatystów od czasów wojny rosyjsko-ukraińskiej z 2014 roku.

Ostatni omawiany kościół na Lewobrzeżu Ukrainy został wybudowany w latach 1902-1903 w Bachmucie, w guberni jekaterynosławskiej. Inicjatorem powstania świątyni pw. Wniebowzięcia Najświętszej Maryi Panny była miejscowa wspólnota parafialna. Władze sowieckie zamknęły kościół i przeznaczyły go do celów świeckich. W dniu 9 kwietnia 2005 roku budynek kościoła oficjalnie został przekazany wiernym. Świątynię pw. Matki Bożej Królowej Różańca Świętego konsekrował biskup Stanisław Padewski. Nadal trwa jednak jej remont ${ }^{97}$.

94 Костел Святого Миколая у Дніпродзержинську, https://we.org.ua/malovnychi-kutochky-ukrayiny/dnipropetrovska-oblast/kostel-svyatogo-mykolaya-u-dniprodzerzhynsku/ (dostęp: 24.12.2019).

95 Слоневський, Коротка історія римо-католицької парафії м. Кам'янське (Дніпродзержинськ), http://www.snicola.net/parafiya/istoriya-parafi\%d1\%97/ (dostęp: 29.12.2019).

${ }_{96}$ Снакієве. Костел бл. Терези Калькутської і Воздвиження Святого Хреста, http://rkc. in.ua/index.php? \&m=k\&f=ahz\&p=do_entr\&l=u(dostęp: 8.01.2020).

${ }_{97}$ Бахмут (Артемівськ). Костел Матері Божої Святого Розарію, http://rkc.in.ua/index. $\mathrm{php} ? \& \mathrm{~m}=\mathrm{k} \& \mathrm{f}=\mathrm{ahz} \& \mathrm{p}=$ doararmb\&l$=\mathrm{u}($ dostęp: 8.01 .2020$)$. 
Reasumując, należy stwierdzić, że w ciągu XIX wieku w miastach Lewobrzeżnej Ukrainy trwał proces kształtowania się wspólnot polskich. Dzięki ich aktywności, przy wsparciu wpływowych mecenasów zbudowano dwanaście kościołów rzymskokatolickich na terenie czterech guberni ukraińskich. Od momentu konsekracji kościół stawał się centrum życia nie tylko społeczności polskiej, ale także miejscem spotkań katolików różnych narodowości. Władze sowieckie po zajęciu Ukrainy w 1919 roku najpierw zamknęły kościoły, a następnie część z nich zburzyły lub przebudowały na cele świeckie. Dzisiaj funkcjonują świątynie w Charkowie, Sumach, Dnieprze, Kamienieńskim i Romnach. Budowle kościołów zachowały się również w Czernihowie i Krzemieńczuku, nie pełnią jednak one funkcji sakralnych.

\section{BIBLIOGRAFIA}

\section{Opracowania}

Bakowećka Olha, Rymo-katolyćka cerkwa w Ukrajini w kinci XVIII-XIX stolitti, Mykołajiw 2015.

Iwaniuk Oleg, Etnicznyj skład miśkoho nasełennia Czernihiwśkoji huberniji naprykinci XIX st. za matieriałami opublikowanych statystycznych dokumentiw Rosijśklji imperiji, „Literatura j kultura Polissia”, 51 (2009) c. 114-119.

Kijas Artur, Polacy na Uniwersytecie Charkowskim 1805-1917, Poznań 2008.

Księga pamiątkowa inżynierów cywilnych Polaków wychowanków Instytutu Inżynierów Cywilnych w Petersburgu, Warszawa 1937.

Kuszłakowa Natalija, Inżenery-architektory polśkoho pochodżennia w Charkiwśkomu widditenni Imperatorśkoho Rosijśkoho technicznoho towarystwa, „Istorycznyj Archiw", 3 (2009) c. 118-122.

Lipiński Teodor, Polacy w Charkowie, „Znicz. Kalendarz informacyjny z działem literackim za rok zwyczajny", 1 (1905) s. 71-139.

Lisewycz Iwan, Duchowno sprahli: Duchowne żyttia polśkoji nacionalnoji menszyny na Naddniprianśkij Ukrajini w 1864-1917 rr., Kyjiw 1997.

Łukawski Zygmunt, Ludność polska w Rosji 1863-1914, Wrocław-Warszawa-Kraków 1978.

Mądzik Marek, Korzeniowski Mariusz, Latawiec Krzysztof, Tarasiuk Dariusz, Polacy na wschodniej Ukrainie w latach 1832-1921, Lublin 2014.

Omilanowska Małgorzata, Bilewicz Hubert, Architektura, polityka, tożsamość. Z badań nad karierami polskich wychowanków rosyjskich uczelni architektonicznych $w$ XIX i na poczatku XX wieku (casus Józefa Padlewskiego), w: Polska-Rosja. Sztuka i historia. Sztuka polska, sztuka rosyjska i polsko-rosyjskie kontakty artystyczne do poczatku $X X$ wieku, red. J. Malinowski, I. Gawrasz, N. Mizerniuk-Rotkiewicz, Warszawa-Toruń 2013, s. 293-305.

Polakowa Julianna, Architietory Char'kowa polskogo proischożdienija, w: Polska diaspora w Charkowie. Historia i wspótczesność, Charkiw 2014, s. 128-144.

Riejngardt Fiedor, Rimsko-Katoliczeskaja cerkow' w Char'kowie, w: Char'kowskij Sbornik. Litieraturno-naucznoje pritożenijek Char'kowskomu Kalendariu na 1887 g., Char'kow 1887, s. 260-261. 
Rublowa Natalija, Antykostiolna kampanija w USRR: pryczyny, instrumentarij, perebih (kineć 20-ch-30-ti rr.), ,Z archiwiw WUCZK-HPU-NKWD-KHB”, 1 (1996) s. 388405.

Rublowa Natalija, Peredmowa, „Z archiwiw WUCZK-HPU-NKWD-KHB”, 2 (2003) s. 17-48.

Rublowa Natalija, Rymo-katołyćka cerkwa w ukrajinśkij prowiciji 1920-1930 ch. rr., Fastiwszczina, ,Z archiwiw WUCZK-HPU-NKWD-KHB”, 1 (2012) s. 258-332.

Zajonc Cży, Niewidomi dżerieła istorï pierszoï pols'koürimo-katolic'koï parafï u Charkowi, ,Wisnik Charkiws'kogo nacionalnogo uniwiersitietu imieni W. N. Karazina”, 74 (2016) c. 314-321.

Żur Michaił, Istorija rimo-katoliczeskoj cerkwi w Char'kowie, w: Polśka diaspora u Charkowi: istorija ta suczasnist', red. I. Żurawlowa, Charkiw 2004, s. 8-20.

Żwanko Lubow, Polonia Charkowa w XVIII-XIX wieku, ,Wiadomości Historyczne z Wiedzą o Społeczeństwie", 6 (2016) s. 26-29.

Żwanko Lubow, Polacy na Ukrainie Lewobrzeżnej: geneza, symbole tożsamości (XIXpoczątek XX wieku), „Europa Orientalis”, 8 (2017) s. 21-46.

Żwanko Lubow, Polscy architekci Charkowa - Bolesław Michałowski i Marian Józef Zdzisław Charmański: szkic o życiu i twórczości, „Studia z Architektury Nowoczesnej”, 6 (2018) s. 47-69.

Żwanko Lubow, Wybitni Polacy i Charków: słownik biograficzny (1805-1918), thum. T. Dowżok, Charków 2019.

Żwanko Lubow, Spuścizna architektów Polaków na mapie Charkowa, w: Polskije i rossijskije architiektory $w$ XIXIXX wiekach. Polish and-russian architects in 19-th And 20th Centuries, t. 4, red. J. Malinowski, I. Gawrasz, Warszawa-Toruń, 2018, s. 181-196.

\section{Netografia}

Bachmut (Artemiwśk). Kostet Materi Bożoji Swiatoho Rozariju, http://rkc.in.ua/index. $\mathrm{php} ? \& \mathrm{~m}=\mathrm{k} \& \mathrm{f}=\mathrm{ahz} \& \mathrm{p}=\mathrm{doararmb} \& \mathrm{l}=\mathrm{u}($ dostęp: 8.01.2020).

Bielawśka Oksana, Architektura połtawśkych chramiw poreformenoji doby, https:/archcity. pro/2017/10/16/arhitektura-poltavskyh-hramiv-poreformenoyi-doby/(dostęp: 24.12.2019).

Chram Petra i Pawła (Niżyn), https://uk.wikipedia.org/wiki/ (dostęp: 23.12.2019).

Czabanmykoła, Rodyna architektoriw Brodnyćkych na Katerynosławszczyni, http://www. sicheslav.porogy.org/2007/13/historyland/ (dostęp: 15.05.2017).

Czernihiw. Kostet Uspinnia Preswiatoji Diwy Mariji ta sw. Joana Chrestytela, http://rkc. in. ua/index.php? $=\mathrm{r} \& \mathrm{~m}=\mathrm{k} \& \mathrm{f}=\mathrm{occg} \_\& \mathrm{p}=\mathrm{cg} \_$cgud (dostęp: 21.12.2019).

Czernihiw. Kostet Zisłannia Swiatoho Ducha, http://www.rkc.in.ua/index.php?\&m=k\&f $=$ akzcg_\&p=cg_cgsd\&l=u (dostęp: 29.12.2019).

Istorija soboru, http://cmcobor.in.ua/page/storja-soboru (dostęp: 23.12.2019).

Jasenczuk Ołeksandr, Czernihiw polśkyj: sztrychy do etnicznoho portretumista http://pivnich. info/chernihiv-polskyj-shtryhy-do-etnichnoho-portretu-mista/ (dostęp: 21.12.2019).

Jenakijewe. Kostel bt. Terezy Kalkutśkoji i Wozdwyżennia Swiatoho Chresta, http://rkc. in.ua/index.php? $\& \mathrm{~m}=\mathrm{k} \& \mathrm{f}=\mathrm{ahz} \& \mathrm{p}=\mathrm{do} \_$entr\&l=u (dostęp: 8.01.2020).

Kosteł Błahowiszczennia Preswiatoji Diwy Mariji (Sumy), https://uk.wikipedia.org/wiki/ (dostęp: 26.12.2019).

Kostet Neporocznoho Zaczattia Preswiatoji Diwy Mariji (Romny), https://uk.wikipedia. org/wiki/ (dostęp: 8.01.2020).

Kostet swiatoho Josypa (Dnipro), https://uk.wikipedia.org/wiki/ (dostęp: 23.12.2019).

Kostet Swiatoho Mykołaja u Dniprodzerżynśku, https://we.org.ua/malovnychi-kutochky-ukrayiny/dnipropetrovska-oblast/kostel-svyatogo-mykolaya-u-dniprodzerzhynsku/ (dostęp: 24.12.2019). 
Kostety $i$ kaptyci Ukrajiny, http://rkc.in.ua/index.php?\&m=k\&f=akzcg_\&p=cg cgud\&l=u (dostęp: 29.12.2019).

Kostiol Swiatych Petra $i$ Pawła, https://nizhyn-travel.com.ua/uk/pages/47-kostol svyatyx_petra_i_pavla (dostęp: 26.12.2019).

Katołyćkomu chramu w Sumach bilsze sta rokiw, http://www.websu.info/archives/3754 (dostęp: 26.12.2019).

Kremenczuk. Kostel sw. Josyfa (staryj), http://rkc.in.ua/index.php?\&m=k\&f=ahzpo $\& \mathrm{p}=\mathrm{po} \_$krks\&l$=\mathrm{u}($ dostęp: 24.12 .2019$)$.

Kremenczuk. Kostel sw. Josyfa, http://rkc.in.ua/index.php?\&m=k\&f=ahzpo_\&p=po krks \&l=u (dostęp: 24.12.2019).

Łuka Nazarowycz Semko-Sawojśkyj, https://uk.wikipedia.org/wiki/\% (dostęp: 8.01.2020).

Mariupol (Domacha, Pawłowśk, Żdanow). Kostet Uspinnia Preswiatoji Diwy Mariji, http://rkc.in.ua/index.php? $=\mathrm{u} \& \mathrm{~m}=\mathrm{k} \& \mathrm{f}=\mathrm{osdo} \quad \& \mathrm{p}=\mathrm{do} \quad \operatorname{mpud}($ dostęp: 24.04 .2017$)$.

Pawłohrad. Kosteł sw. Archanheła Mychajiła, http://www.rkc.in.ua/index.php?\&m=k\&f $=$ ahzdppg\&p=dppgpgmh \&l=r (dostęp: 15.02.2020).

Romny. Kostel Neporocznoho Zaczattia Preswiatoji Diwy Mariji, http://www.rkc.in.ua/ index. $\mathrm{php} ? \& \mathrm{~m}=\mathrm{k} \& \mathrm{f}=\mathrm{ossuro} \& \mathrm{p}=$ suroronz $\& \mathrm{l}=\mathrm{u}$ (dostęp: 8.01.2020).

Ryms'ko-katołycka parafija u Kremenczuci, https://www.05366.com.ua/news/674415/rimsko-katolicka-parafia-u-kremencuci (dostęp: 24.12.2019).

Semko-Sawojśkyj Łuka Nazarowycz, https://uk.wikipedia.org/wiki (dostęp: 24.04.2017).

Slonewskij Aleksandr, Żizn. Smert. Woskresenie. Dnepropetrowsk 2009, https://sobitie.com. ua/istoriya/aleksandr-slonevskiy-kniga-zhizn-smert-voskresenie-chast-i-glavy-5-8 (dostęp: 18.02.2020).

Słonewskyj Ałeksandr, Ystoryczeskaja zahadka: kto bult archytektorom kostëta Swiatoho Nykotaja?, https://stsergiydndz.wixsite.com/library/slonevsky-istoricheskaya-zagak (dostęp: 24.12.2019).

Słonewśkyj Ołeksandr, Korotka istorija rymo-katołycḱkoji parafiji m. Kamjanśke (Dniprodzerżynsk), http://www.snicola.net/parafiya/istoriya-paraf\%od1\%97/ (dostęp: 29.12.2019).

Starostin Wałentyn, Polśka rodyna katerynosławśkych architektoriw, http://archive.li/ 7BBuj \#selection-1217.0-1417.30 (dostęp: 12.05.2017).

Starostyn Wałentyn, Rymsko-katołyczeskyj kostel w Ekaterynosławe. Chram Sw. Josypa, https:/www.shukach.com/ru/node/889 (dostęp: 24.12.2019).

Trehubow Wałerij, Rymo-katołyckyj Chrestozdwyżenskyj kostiol w Pottawi, http://histpol. pl.ua/ru/pamyatniki-istorii-i-arkhitektury/religioznye-sooruzheniya?id=7925 (dostęp: 24.12.2019).

Utraczennyje chramy Mariupola, https://ru.wikipedia.org/wiki/ (dostęp: 26.12.2019).

Хрестоздвиженський костел (Полтава), https://uk.wikipedia.org/wiki/ (dostęp: 22.12.2019).

Zodczi, inżenery, chudożnyky, szczo brały uczast' u formuwanni Katerynosława, http:// forum.cebos.com.ua/viewtopic.php? $\mathrm{f}=2 \& \mathrm{t}=126$ (dostęp: 8.01.2020).

Żur Mychajło, Istorija rymśko-katołyckoji parafiji w Charkowi, https://catholic-kharkiv.org/yeparhiya/istoriya/istoriya-rimsko-katolitskoyi-parafiyi-v-harkovi/ (dostęp: 20.05.2017).

Шруб Константин, Люди Днепра: архитекторы Бродниикие, https:/gorod.dp.ua/ news/168079 (dostęp: 24.12.2019). 


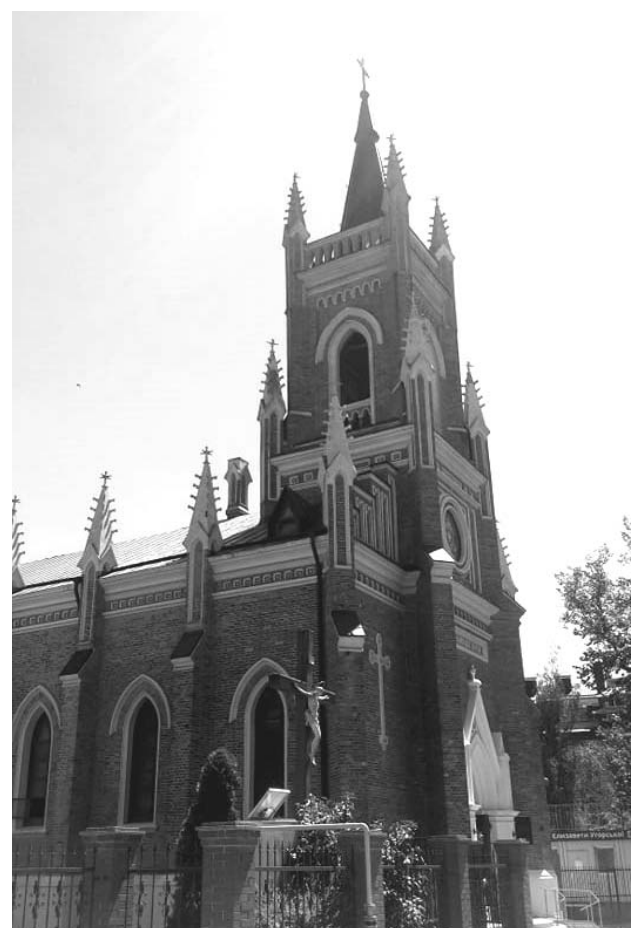

Il.1. Kościół katedralny pw. Wniebowzięcia Najświętszej Maryi Panny, Charków. (Fot. L. Żwanko).

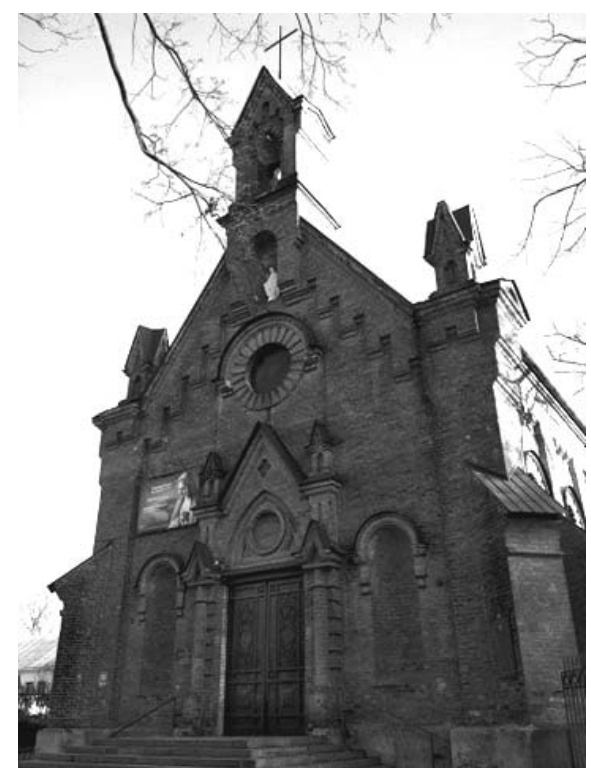

I1.2. Kościół pw. Zwiastowania Najświętszej Maryi Panny, Sumy. (Fot. L. Gonczarenko) 


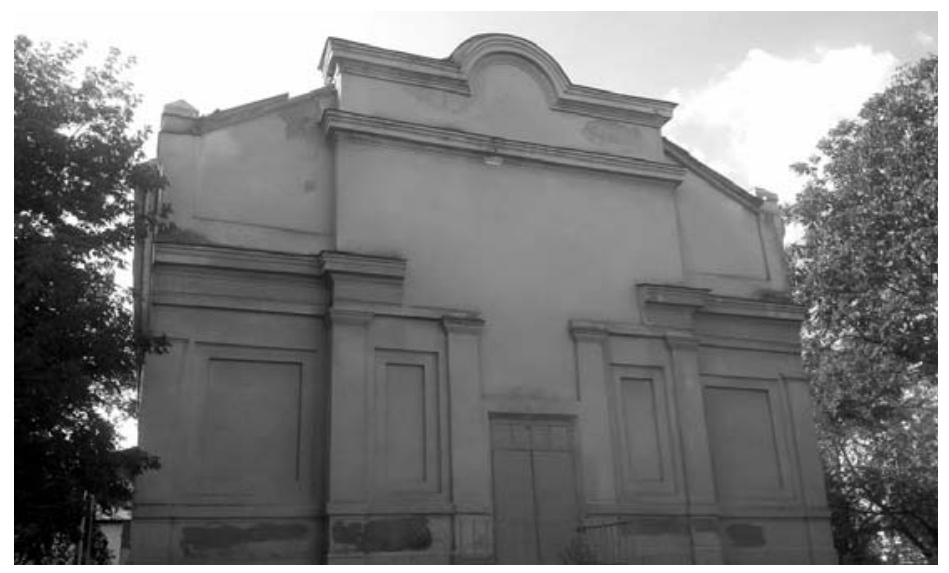

I1.3. Kościół pw. Wniebowzięcia Najświętszej Maryi Panny i świętego Jana (Joanna) Chrzciciela, Chernihów.

(Źródło: http://4ernigiv.info/strichka/29111-kostel-svyatogo-aleksandra-ulica-pyatnickaya.html)

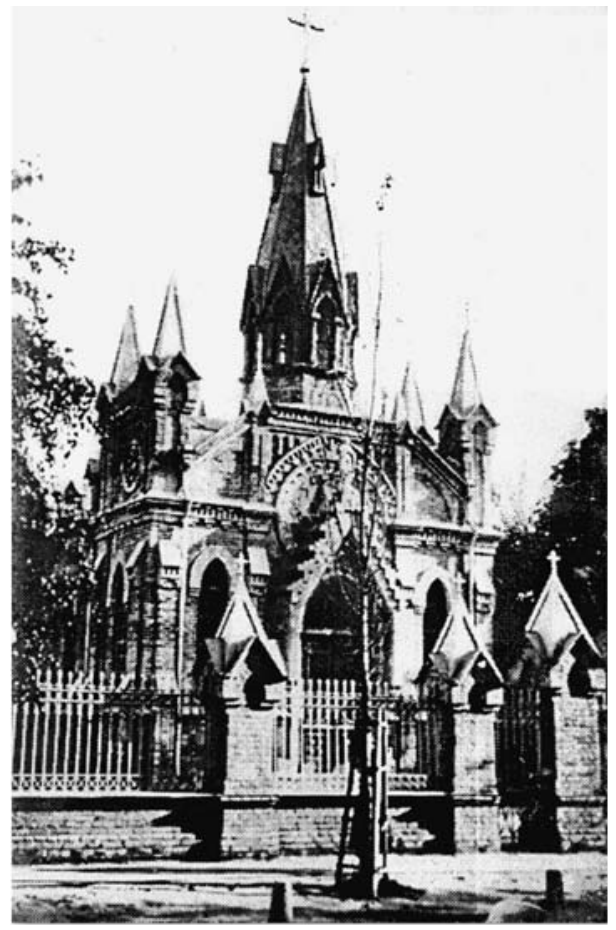

Il.4. Kościół pw. św. Piotra i Pawła, Nieżyn.

(Źródło: https://nizhyn-travel.com.ua/uk/pages/47-kostol_svyatyx_petra_i_pavla). 


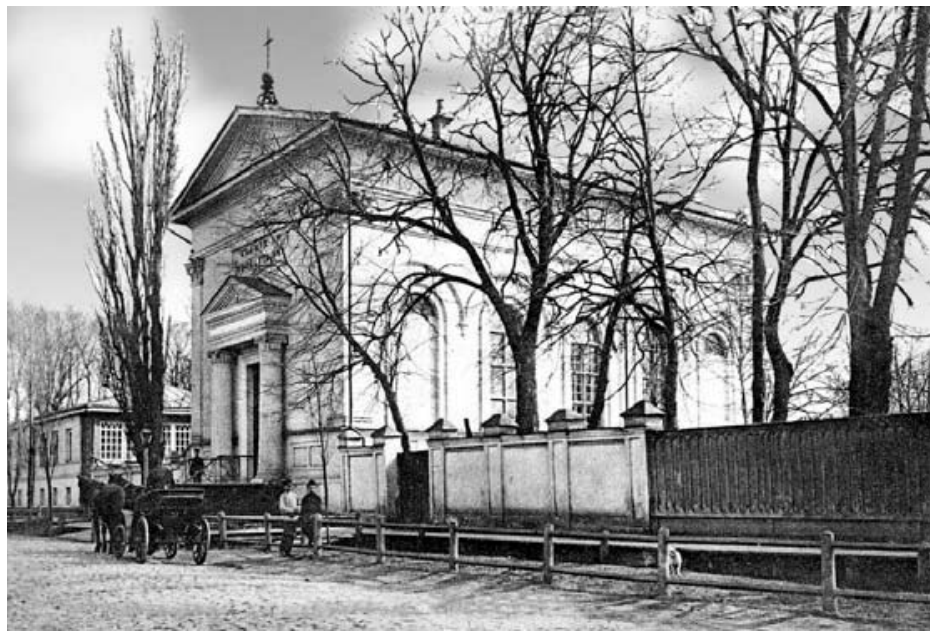

Il.5. Kościół Chrestozdwyżeński, Połtawa

(Źródło: http://histpol.pl.ua/ru/ pamyatniki-istorii-i-arkhitektury/religioznye-sooruzheniya?id=7925).

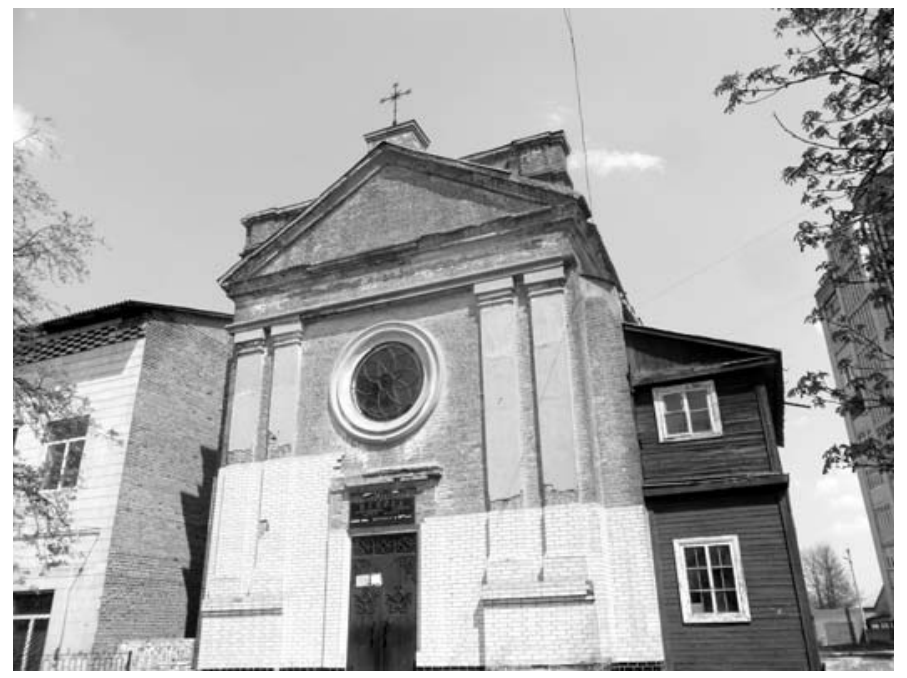

I1.6. Kościół pw. Niepokalanego Poczęcia Najświętszej Maryi Panny, Romny. (Fot. O. Loboda; źródło: https://uk.wikipedia.org/wiki/) 


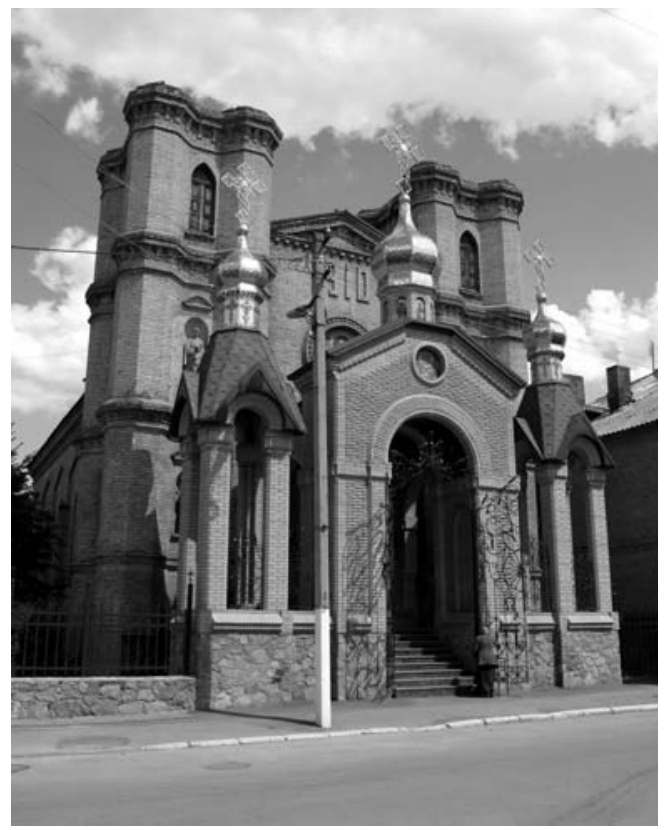

Il.7. Kościół pw. św. Józefa, Krzemieńczuk.

(Źródło: http://okrain.net.ua/up/photos/star_kremen/11/kremkost_1915.jpg)

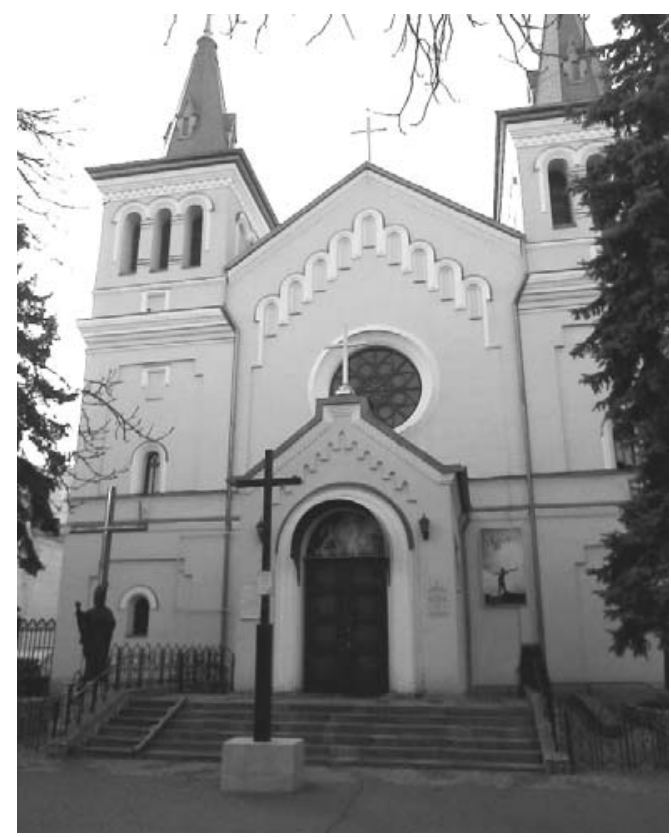

Il.8. Kościół św. Józefa, Jekaterynosław (Dnier).

(Fot. J. Beresteń). 


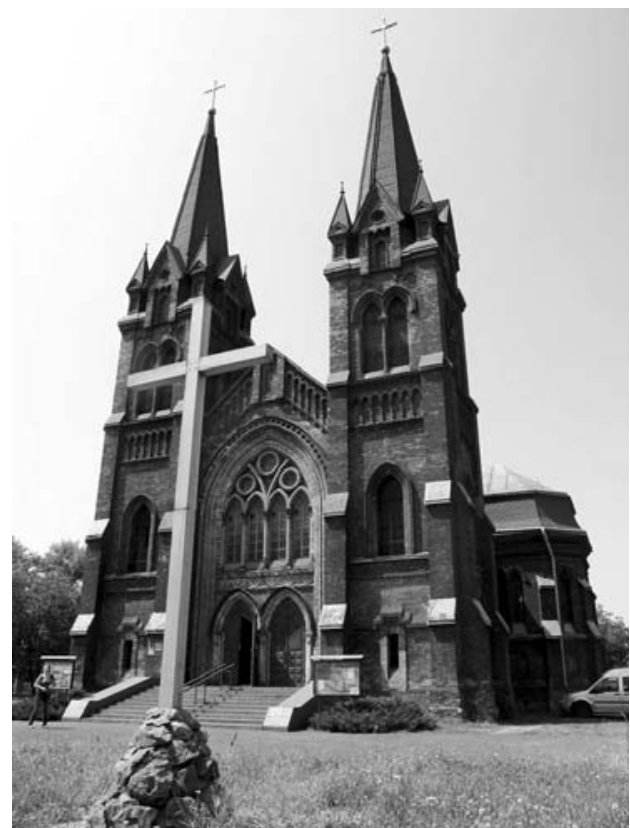

I1.9. Kościół pw. św. Mikołaja, Kamienskoje.

(Fot. L. Szewczenko).

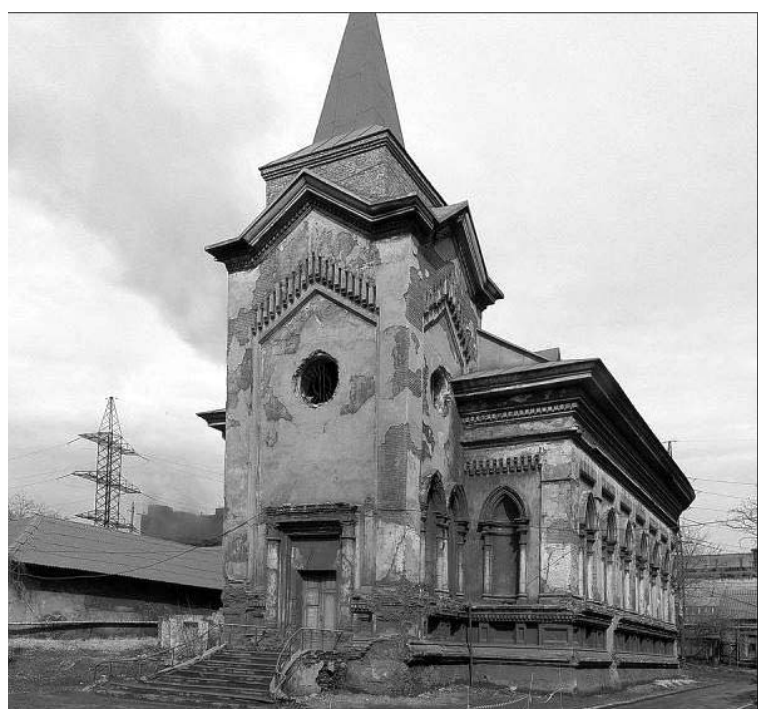

Il.10. Kościół pw. Podwyższenia Krzyża Świętego, Jenakijewo. (Źródło: https://linkd.pl/uea4) 


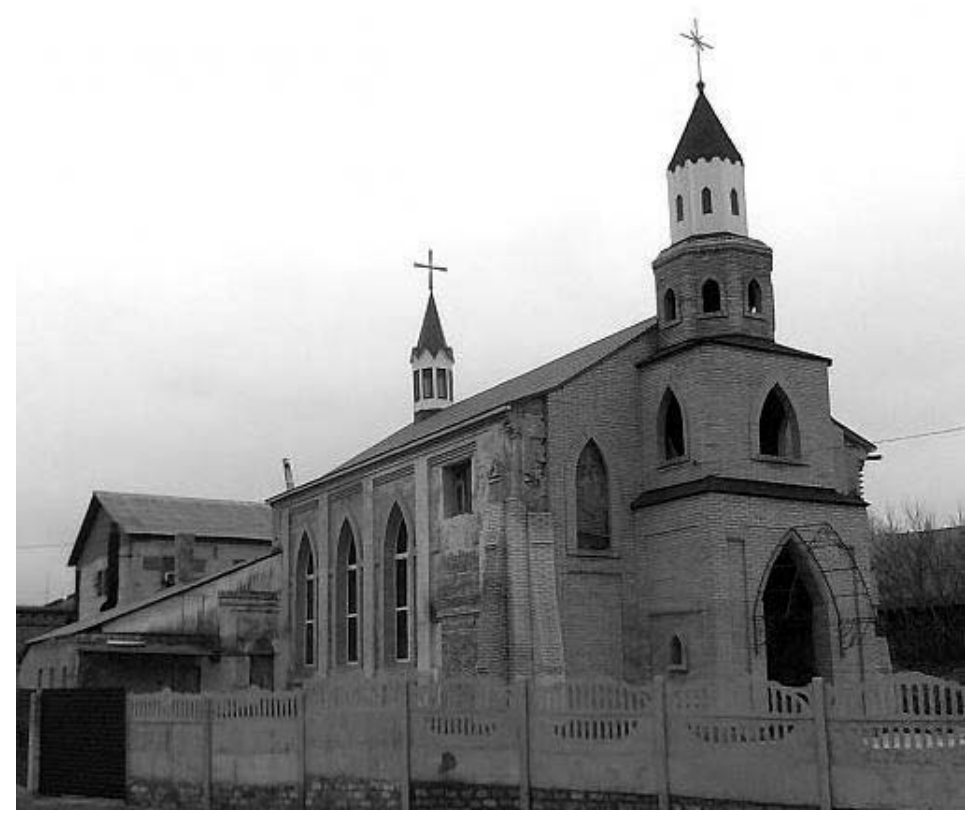

Il.11. Kościół Wniebowzięcia Najświętszej Maryi Panny, Bachmut. (Źródło: https://linkd.pl/ueaz). 


\section{ROMAN CATHOLIC CHURCHES \\ IN LEFT-BANK UKRAINE (19TH-20TH CENTURY). A RETROSPECTIVE ANALYSIS}

\section{Summary}

This article provides a short retrospective of the history of Roman Catholic churches in Left-Bank Ukraine in the 19th-20th century, from construction during the Russian Empire to their fate in the Soviet era. It also mentions the contemporary situation of churches in independent Ukraine. Firstly, the factors that caused the establishment of numerous Polish communities in the areas of Left-Bank Ukraine, i.e. in the Yekaterinoslav, Poltava, Kharkiv and Chernihiv Governorates, were analysed. Thanks to the efforts of local Poles 12 churches were built in this area, namely in: Chernihiv, Nizhyn, Poltava, Romny, Kremenchuk, Yekaterinoslav, Kamianske, Yenakiieve, Mariupol, Bakhmut, Kharkiv and Sumy.

In the summary of the article it was pointed out that every church, since its consecration, had become a centre of life not only of the Polish community, but also a meeting place for Catholics of different nationalities. During the occupation of Ukraine by the Bolshevik army, the churches were closed and some of them demolished. Only a few temples have survived to our times. Today, they are important remnants of sacral architecture, decorating the centres of Ukrainian cities.

Keywords: church; Left-Bank Ukraine; sacral architecture; Polish minority; Polish community 